\title{
2 AMAR
}

AMAR (Andalas Management Review)

Vol. 3, No. 1 (2019) page 19-54

The Management Institute, Faculty of Economics, Andalas University

ISSN (Print) 2476-9282 | ISSN (Online) 2548-155X

\section{Influencing Factors in the Depth-Usage of Social Media as the Business Platform by Student Entrepreneurs}

\author{
Hafiz Rahman, Rahmad Hidayat \\ Department of Management, Faculty of Economics, Universitas Andalas \\ hafiz.rahman@fekon.unand.ac.id
}

\begin{abstract}
This paper examines factors that influence the depth-usage of social media as a business platform among student entrepreneurs by focusing analysis on the mediating effect of social media adoption. The study uses The Unified Theory of Acceptance and Use of Technology (UTAUT) Model which identifies factors that can influence individuals' behavioral patterns to accept and to use technology as the main theoretical/conceptual foundation.

The study is a quantitative study which operates relational analysis between variables. A survey through the questionnaire with 142 student entrepreneurs in three state owned universities in Padang, Indonesia was undertaken to collect primary data and information. The result was further analyzed by using Structural Equation Modelling (SEM) Partial Least Square (PLS) and causal step analysis in order to investigate the relationship between each variable and the mediating effect of social media adoption on factors that influence the depth-usage of social media as the business platform used by students entrepreneurs.

The study found that performance expectation, perceived trust and social influence as the major factors that influence the adoption of social media usage as the business platform by student entrepreneurs. Meanwhile, perceived risks does not bring positive and significant influence. However, the mediating effect of the adoption of social media usage is only found in the performance expectancy when it influences the depth-usage of social media as the business platform by the student entrepreneurs.
\end{abstract}

Keyword: UTAUT Model, social media, business platform, student entrepreneurs

\section{INTRODUCTION}

Information and Communication Technology (ICT) has become a major demand in every people's activity throughout the world. The development of ICT, and currently, the rise of Industrial Revolution (IR) 4.0 have created significant changes in every sector, including business sector. Traditional business operation has transformed itself into a more modern and sophisticated form, which we have known as electronic business (e-business) or online 
business. According to Porter, (2003) e-business or online business can be understood as a business entity which uses internet in its business operation throughout the value chain. The depth-use of ICT can be signed by the adoption of internet in every activity. In Indonesia for example, the growth of internet users is considered very high - and in fact, the highest in Asia. Report from Indonesian Association of Internet Service Providers (APJII) also revealed that the number of internet users in Indonesia is always increasing every year. In 2017 only, internet user in Indonesia has reached 143,26 millions users or 54.68\% from the total Indonesian population. Based on the geographical consideration, the Island of Java contributes the biggest percentage of internet users in Indonesia - reaching 58.08\% from all population, followed by the island of Sumatra with $19.09 \%$ of all population, Kalimantan (7.97\%), Sulawesi (6.73\%) Bali and Nusa Tenggara (5.63\%) and Maluku and Papua (2.49\%), APJII, (2017). Rapid development in ICT is the main factor which boosts internet users in Indonesia.

According to another survey undertaken by APJII, social media is the main internet content that has been very popular in Indonesia, APJII (2017). Total social media users in Indonesia reach 129.4 million users (97.7\% of all internet users), followed by entertainment that reaches 128.4 million users (96.8\%), news that reaches 127.9 million users $(96.4 \%)$, education that reaches 124 million users, commercial that reaches 123.5 million users and public services that reach 121.5 million users. From 123.5 million users who use internet for commercial purposes, 82.2 million users are accessing online sites and the rest 45.3 million users are using internet for personal business purposes. Based on age, internet users are dominated by population aged 19-34 years old, reaching 70.94 millions users or $49.52 \%$ of all population, (APJII, 2017). The biggest penetration of internet users is students in higher education institution (18 million users or $89 \%$ of the internet users). Facebook has become the main social media content for Indonesian internet users. APJII has reported that the number of Facebook users reaches 71.6 million users (54\% of all users), followed by Instagram (19.9 million users), and YouTube (14.5 million users), APJII (2017).

As mentioned, there are 123.5 million users who use internet for commercial purposes, which part of them are using business to business transaction, and business to customers transaction. According to Indonesian Ministry of Cooperatives and the Empowerment of SMEs, there are 3.79 millions SMEs that have already used and taken benefits from online platform in their business operation. We can see from this data and situation that online platform would be 
a great chance and opportunity for Indonesian SMEs to become a major player. In 2019, Indonesian government has targeted 8 million SMEs to go-online, (Indonesian Ministry of Cooperatives and the Empowerment of SMEs, 2017).The massive number of social media users in Indonesia and its advantages have become the main factor that boosts business people to use social media in their business. Millions of people use social media - so there will be big chances for business people to bring their business to the public by using the social media (Qualman, 2009). Some studies have proven that the social media is very useful in business and it also brings benefit and significant motivations for entrepreneurs (Hite and Hesterly, 2001).

In West Sumatra, APJII revealed that there are 1.8 million internet users in 2014 with the number of penetration reaches 35\% from the total population (around five million people). Using this estimation, APJII calculated that in 2017, internet users in West Sumatra have reached 2.9 to 3 million users - where the big city and its surrounding areas are the region with the highest internet penetration (72.4\%). Padang, Bukittinggi and Payakumbuh become the major cities which have the biggest internet users in West Sumatra.

The use of internet in business operation has brought significant benefits for business, such as a speedy operation, lower costs, user friendly, broader coverage in reaching the customers, and can be used as a platform to establish good relationship with the customers, (Larpsiri and Speece, 2003). Those benefits have stimulated business people either those who have small scale or big scale businesses to use internet as their main platform to support their business. The situation also occurs to students in higher education institution, who runs businesses by their own and have taken benefits from the existence of internet technology. Social media is the major internet content that has been used by nascent entrepreneurs and student entrepreneurs as the platform for their business.

Even though it is understood that students have a very big potential to become an entrepreneur, however some studies and research revealed that number of students who actually establish businesses is minimum (Shambare, 2013) and sometimes, their existence cannot be traced. This phenomenon can be found in the data released by each state owned higher education institutions in Padang through their Career Development and Entrepreneurship Unit, which show a very less number of students entrepreneurs in each institution. Based on that data, student entrepreneurs in three biggest state owned higher education institutions in Padang are just 243 student entrepreneurs (Universitas Andalas 101 
student entrepreneurs, Padang State Polytechnic 97 student entrepreneurs, and Padang State University 45 student entrepreneurs). An initial investigation undertaken by the researchers found that almost all student entrepreneurs use social media to support their business activities such as for promotion and marketing, distribution of the product, finding and establishing business network and maintaining good relationship with their loyal customers. This is in line with the study from Lee et al., (2014) who argued that the social media has brought a significant impact and influence to internet users, and has become a major fundamental basis that creates customers' attitude and life style. Velldeman et al. (2015) have further stressed that the social media has become a major effective media for selling, marketing and communicating the business to the customers in the globalized era. Social media is also bringing possibilities for the company to have faster communication with their customers, creating competitiveness and can further contribute to the development of SMEs by neutralizing the geographical burden (Jagongo and Kinyua, 2013) and can transform potential customers into an actual one (Mangold and Faulds, 2009).

The phenomenon and the rise of students entrepreneurs as well as the rapid use of ICT, particularly the social media in the business, have brought an interesting question regarding the actual factors which may influence the depth-use of social media by student entrepreneurs. Using the Unified Theory of Acceptance and Use of Technology (UTAUT) Model which identifies factors that can influence individuals' behavioral patterns to accept and to use the technology as the cornerstone, the study aims at investigate the mediating effect of the adoption of the use of social media in the influence of performance expectancy, perceived trust, perceived risk and social influence to the depth-use of social media as the business platform by student entrepreneurs. As the context, this study was undertaken with students entrepreneurs in Indonesian government owned higher education institutions in Padang, Indonesia.

According to Bailetti (2011), student entrepreneur is an individual in a young mature age, who establishes a new venture to commercialize opportunity by using knowledge getting from their study in the university and can change knowledge into products and services with the assistance of innovative technology which further brings financial benefit. Student entrepreneurs are categorized as nascent entrepreneur in which with their nature and characteristics, play a major role in the innovation and performance of entrepreneurship of a region (Fueglistaller et al., 2006). Student entrepreneurs are also those who are characterized as 
'dream merchants' (Purewal, 2001), or those who are yearning to do different things by contributing to the world with a purposeful intrinsic motivation (Pink, 2009), can intuitively formulate plans (Mintzberg, 1983), can establish emerging businesses rather than extending and defending existing businesses (Baghai et al., 2000) and more importantly, those who can capitalise on opportunities arising from the market transitions and business model shifts (Fryer et al., 2008) in advance of the global marketplace. Demographically and a more detailed personal characteristics of student entrepreneurs are further offered by Marchand and Sood, (2014) who mentioned that the student entrepreneurs are those who: [a] are 18-25 years of age and undergraduate, [b] enrol in an university award programme or equivalent, and [c] lead a student association or start-up business while studying. Those personal characteristics and the development of ICT and currently, the issue of industry 4.0, have opened a very big opportunity for students to become a major internet based business players, which mostly use social media as the business platform.

The use of social media as a business platform has increased the comfortability of the customers and potential customers. Using this platform will let them easier to give comments and suggestion to improve companies' products and services into a better one (Evans, 2010). Meanwhile, for student entrepreneurs, social media can be used to find business ideas, to introduce products, to improve everything related to the business and products, to broaden market coverage, to communicate with customers, broadening networks, innovation through new technology and experiments (Evans, 2010) etc. - and the most important point is that students can still pursue their tasks and responsibility as a student.

Currently, the most frequent social media that is used as a business platform consists of Facebook, Twitter, Instagram, LinkedIn and YouTube. These platforms have been used not only by students and nascent entrepreneurs, but also the more established and settled companies. Each of this social media has brought particular impact in entrepreneurial and business strategies based on the particular considerations from entrepreneurs and companies. Facebook, for example, can offer a very cheap product publicity which is very easy to manage by the company (Ellison et al., 2007). In YouTube, the company can create tutorial video to facilitate its customers in using the products, share knowledge about the products, and the most important thing, can viral it in the internet and other social media (Brown, et al., 2007). Twitter in the other hand, has a distinctive feature. In one side, company can monitor respond and opinion from 
Andalas Management Review, Vol. 3 No. 1, 2019

customers and public about its operation in the social networks. On the other side, company can also advertise their product to other social media platforms.

\section{The Unified Theory of Acceptance and Use of Technology (UTAUT) Model}

The study uses The Unified Theory of Acceptance and Use of Technology (UTAUT) model to assess the adoption and the depth-use of social media as a business platform by student entrepreneurs. UTAUT Model is considered aas a solid and rigour model that can be used as an integrative theoretical foundation to explain individuals behaviour to accept and to use technology and the diffusion of technology, (Venkatesh et al., 2003). In a bigger scope, Prasetyo and Anubhakti, (2011) mentioned that this model also aims at helping and assisting organization to measure the reaction of users to the introduction of a new technology. The two objectives above can simply show us that UTAUT intends to measure behavioural reaction of either individuals, or organization to the use of technology and the diffusion of technology. As to measuring behaviour is not a simple task to undertake, then broader perspectives from different overviews in order to get fruitful insights and understanding regarding the topic are required. Here is where UTAUT offers its approaches - as a multidimensional approach that can be used as the foundation to measure behavioural reaction to the use of technology and the diffusion of technology by individual, group of individuals and organization. As Noorshella (2017) highlighted, UTAUT has successfully integrated important features from eight major theories which were usually used as the basis and foundation to measure the acceptance of technology. Those theories are: [a] the theory of reasoned action (TRA), [b] the technology acceptance model (TAM), [c] the motivational model (MM), [d] the theory of planned behaviour (TPB), [e] the combined theory of TAM and TPB, [f] the model of PC utilization (MPTU), [g] the innovation diffusion theory (IDT), and [h] the social cognitive theory (SCT).

UTAUT Model has successfully been proven as the basis to explain behaviour of seventy percent of technology users compared with those eight theories when they were used individually. However, based on each theory and model, UTAUT model found seven similar constructs and factors, which occur to be the most significant determinant to behavioural intention or users' behaviour in the use of technology. The constructs/factors are: [a] performance expectancy, [b] effort expectancy, [c] social influence, [d] facilitating conditions, [e] attitude toward using technology, [f] behavioural intention, and [g] self-efficacy, Venkatesh and 
Zhang, (2010). All of those seven constructs and factors could be further categorized into four main dimensions to analyse behavioural intention of technology users. This four main dimensions are:

\section{Performance expectancy}

2. Effort expectancy

3. Social influence

4. Facilitating conditions

In the UTAUT concept and model, performance expectancy, effort expectancy, and social influence are considered as the direct determinant which can explain behavioural intention of individuals in using a certain technology. UTAUT model also considers four moderate variables, which includes [a] age, [b] gender, [c] voluntarily, and [d] experience as factors that can influence determinant of intention and/or attitude of individuals to use technology, (Venkatesh et al, 2003; Venkatesh \& Zhang, 2010).

\section{The Adoption of Social Media Usage}

The adoption process reflects to the acceptance, in which individuals will use something voluntarily, Sumak and Sorgo, (2016). In UTAUT model, the adoption of social media usage refers to behavioral intention which can further reflects the intention of individuals in using a certain technology. According to Claar, et al., (2014) the adoption of social media refers to the level of usage and implementation technology, either in form of software or hardware.

From the overview of potential customers, the adoption of technology is merely used to explore and to search products with an online mode (Soopramanien and Robertson, 2007) because of the lower cost compared with an offline mode. However, the fact shows that the majority of customers still prefer to use and to make transaction with physical stores rather than online/internet stores. This fact is a proove of what Moe and Fader, (2004) previously argued that not all 'adoption' can be converted into 'the usage'.

\section{Performance Expectancy and the Adoption of Social Media Usage}

According to Venkatesh \& Zhang, (2010), performance expectancy refers to the level of belief of an individual whether the use of a certain system can or cannot assist them to improve their working performance. In UTAUT model, perfomance expectancy is formed based on five 
constructs, which is: [a] perceived usefulness (Davis, 1989), [b] extrinsic motivation (Davis et al., 1992), [c] job fit (Thompson et al, 1991), [d] relative advantage (Moore and Benbasat, 1991), and [e] outcome expectations (Compeau et al., 1999). In this study, we view performance expectancy as the level of belief from nascent entrepreneurs to use social media as a system that will assist them in achieving benefits for their business. Social media will enable companies to have a faster communication with their customers, to produce competitive advantage and can neutralize geographic burdens, (Jagongo and Kinyua, 2013). Therefore, the adoption, implementation and the use of social media as the business platform will increase business performance.

Previous study by Foon and Fah (2011) found that performance expectancy has positively and significantly influencing the use of internet banking among banking customers. In entrepreneurship field, Escobar et al., (2014) revealed a positive and significant influence between performance expectancy and e-entrepreurship as a learning platform. A recent study from Shokery et al., (2016) has clearly found that performance expectancy has positive and significant relationship to the adoption of the use of social media as a business platform by the Malaysian students entrepreneurs. Those above mentioned previous studies that revealed the relationship between performance expectancy and the adoption of the use of social media as business platformwas then used as solid basis for us to formulate our first hypotheses, which is: H1: Performance expectancy positively and significantly influences the adoption of the use of social media among students entrepreneurs in the context of study

\section{Perceived Trust and the Adoption of Social Media Usage}

Trust is a cognitive action such as opinion and prediction that something will occur which allows an indvidual to behave in a certain way and in an effective way. Meanwhile according to Gambetta (1988), perceived trust is defined as the level of customers' belief in regards of the product quality and reliability which is offered by a certain organization. In this In this study, we view perceived trust as the level of belief of students entrepreneurs to the reliability of social media platform that they use as the main business platform. We put careful consideration regarding the construct of trust, since it can significantly anticipate the intention of individuals to adopt information technology in each organization (Tung, et al., 2008; Garbarino and Johnson, 2014). In the case of students entrepreneurs, Shokery et al., (2016) mentioned that they 
will only use social media as their business platform if they believe or think that social media is important for the operation of their business.

Analyzing the presence of perceived trust and its relationship to the adoption of social media usage, we can use the studies from Howcroft et al., (2002), Kim et al., (2008) and Noorshella et al., (2017) as the basis for our hypotheses development. Howcroft et al., (2002) revealed that individuals will not use new technology unless they believe that it can give benefits for them. Meanwhile Kim et al, (2008) found that perceived trust positively and significantly influences individuals' behavioral intention in using e-commerce as the business platform. Both those studies were then strengthened by Noorshella et al,. (2017) who marked that perceived trust has a positive and significant relationship to the adoption of social media usage as the business platform. Those three previous studies become our solid basis to develop the second hypotheses for this study, which says:

H2: Perceived trust has a positive and significant influence to the adoption of social media usage by students entrepreneurs in the context of study.

\section{Perceived Risk and the Adoption of Social Media Usage}

Perceived risk can be meant as an uncertainty faced by customers as the consequence of their purchase (Schiffmann and Kanuk, 2000), and therefore it is considered as the main burden for customers to undertake an online business (Kim et al, 2008) and further, to execute transaction within an online business platform. In this study, we view perceived risk as an uncertainty condition and the potential negative outcomes that should be faced by students entrepreneurs in adopting and using social media as their business platform. The risks in business can be in terms of: [a] financial risk, [b] performance risk, [c] product physical risk, [d] psychological risk, [e] time risk, and [f] risk of cost, (Jacoby and Kaplan, 1972; Featherman and Pavlou, 2003).

Previous study from Howcroft, et al., (2002) who investigated customers behavior to use financial services has proven that risk has positively and significantly influenced customers in adopting new technology. Meanwhile, a recent study in the specific topic of perceived risk by Noorshella (2017) found that perceived risk has positive and significant influence to the adoption of social media usage as the business platform among students entrepreneurs in Malaysia. Consistent with the previous studies related to the relationship between perceived 
risk and the adoption of social media usage, we further formulate the third hypotheses in this study, which is:

H3: Perceived risk positively and significantly influences the adoption of social media usage as the business platform among students entrepreneurs in the context of study.

\section{Social Influence and the Adoption of Social Media Usage}

As Kelman (1958), social influence concerns with the change within an individual as a result of the influence from others. Kelman (1958) stressed that attitudes, beliefs, actions and behaviours of individuals will be changed based on referent on others, which is usually occurs through three processes: [a] compliance, [b] identification, and [c] internalization. These three processes are further determined by the presence of three determinants of influence, which consists of: [a] the relative importance of anticipated effects, [b] the relative power of influencing agents, and [c] the prepotency of induced responses. In the use of social media, Venkatesh and Davis, (2000) mentioned that social influence is defined as the level of interest from individuals which is perceived by the belief of others in using social media platform. Therefore, influences from the closest person (friends or relatives) will become a sign of social influence given by others to individuals, (Carlsson et al., 2006).

A study from Tan et al., (2012) found that personal connection such as relatives, supervisor, lecturers, friends and university's environment as well as online community has influenced easier behavioural transformation from the intention to use internet marketing into a more realistic one. This finding has further proven that social influence from families, friends, partners and colleagues, spouse and even, neighbours will encourage people to become more aware to the use of social media as a business platform (Salim, 2012). Previously, there were more evidence showed that social influence has been a major influence for a person to use technology, such as in cellular technology, (Nysveen et al., 2005), information system, (O'Reilly and Chapman, 1986), information technology (Malhotra and Galletta, 1999), the use of Facebook as a social media, Salim, 2012), mobile commerce (Rababa, et al., 2013) Considering those findings, this study has further used them as the foundation to formulate its fourth hypotheses, saying that:

H4: Social influence has positive and significant relationship with the adoption of the social media usage among students entrepreneurs in the context of study. 
Andalas Management Review, Vol. 3 No. 1, 2019

\section{The Adoption of Social Media Usage and the Depth-Usage of Social Media as the Business}

\section{Platform}

Wer are using our understanding regarding the adoption of social media usage by refering to Claar et al., (2014) who previously mentioned that the implementation or the adoption of social media referes to the the level of ability in implementing and using a technology. Meanwhile, the depth-usage of social media refers to the use of the existing technology and the depth level of intensity in using social media as a means of communication, publication and other information regarding products and services (Conole, et al., 2008). Rationally, these two variables have a clear relationship, in which the implementation or the adoption of social media will influence the depth-usage of social media as a business platform. This is further stresed by Soopramanien and Robertson, (2007) who found that the adoption of technology by potential customers were being used to explore and find products in an online mode. Noorshella et al., (2017) also found that the adoption of social media has positively and significantly influenced to the depth-usage of social media a the business platform. All of those previpus studies were used as our basis to formulate the fifth hypotheses, which is:

H5: The adoption of social media usage has positive and significant relationship to the depthusage of social media as the business platform in the context of study.

\section{The Mediating Effect of the Adoption of Social Media Usage}

As the basis to formulate the next hypotheses, we use the study from Noorshella et al., (2017) who argued that the use of social media has significant mediating effect in the relationship between performance expectancy-perceived risk-perceived trust-social influence and the depth-usage of social media. We further formulate the sixth hypotheses of the study which states that:

H6: The adoption of social media usage has mediating positive and significant effect in the relationship between performance expectancy-perceived risk-perceived trust-social influence and the depth-usage of social media as the business platform among students entrepreneurs in the context of study.

\section{The Research Framework}

Based on literature reviews and the development of hypotheses, we then arranged the theoretical framework for this study which is shown in the figure 1 below. 


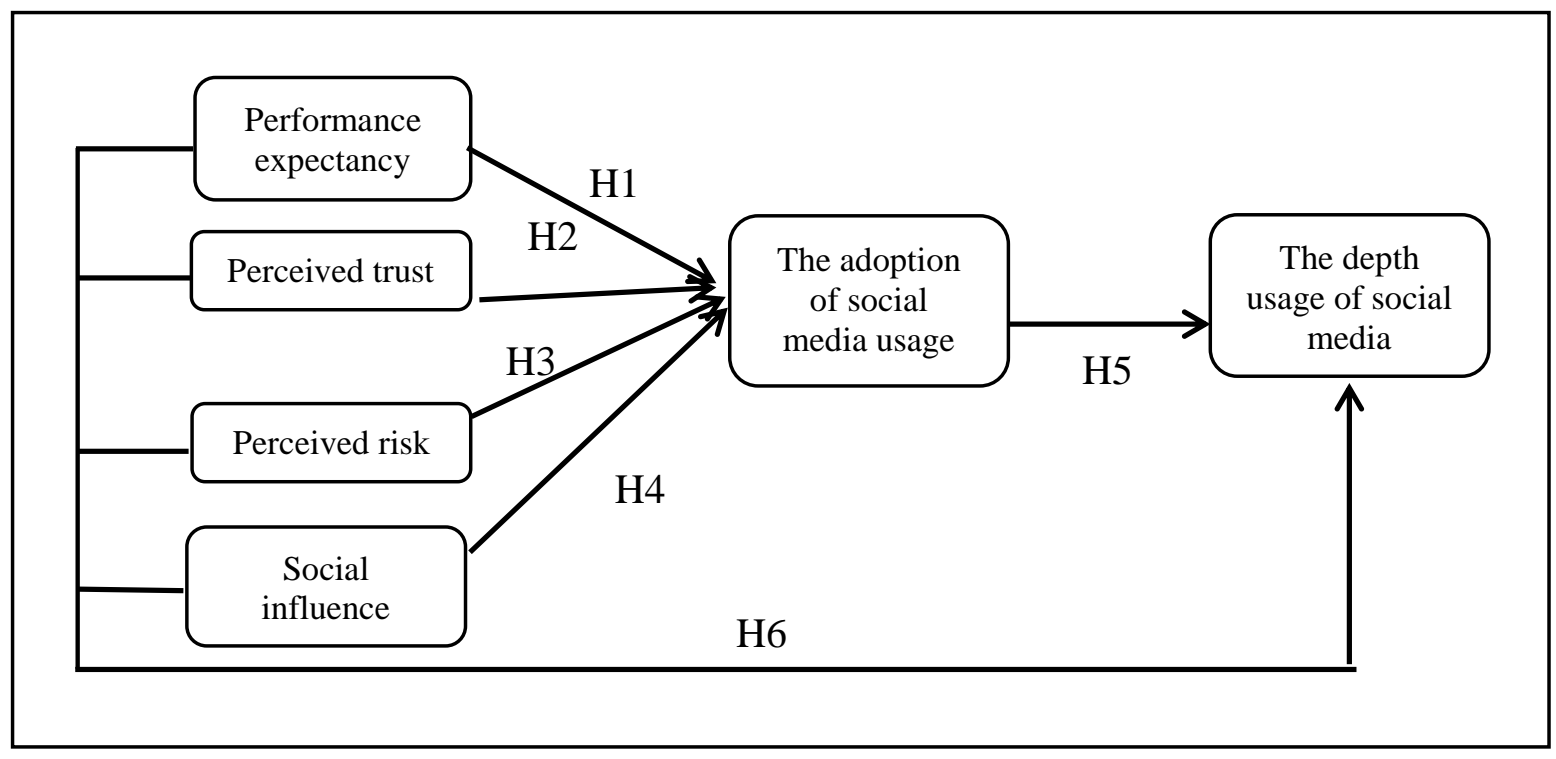

Figure 1. The Research Framework

Source: Conception of the authors, Noorshella et al., (2017).

\section{RESEARCH METHOD}

The study uses quantitative research design by operating cross-sectionl cohort data as the data timeframe to measure the mediating effect of the adoption of social media in the influence of performance expectancy, perception of trust, perception of risk and social influence to the depth-use of social media as the business platform used by students' entrepreneurs. This study is correlational study which intends to find correlation between variables of the study by testing hypotheses that have been previously formulated.

Students' entrepreneurs from three state owned higher education institutions (Universitas Andalas, Universitas Negeri Padang and Politeknik Negeri Padang) which are all located in Padang, Indonesia were operated as the population of study. Detailed number of students' entrepreneurs is collected from entrepreneurship centre of each higher education institution, which has figured the following numbers: [a] Universitas Andalas = 101 students, [b] Politkenik Negeri Padang = 97 students and [c] Universitas Negeri Padang $=45$ students. In total, there are 243 students that have been chosen as population of the study. Sampling technique to identify number of samples uses Isaac and Michael sampling table, which uses 5\% failure rate of all population. Based on Isaac and Michael sampling table and the percentage of failure rate, number of samples that has been used in this study is 142 samples. This 142 samples is then further proportionally distributed to three higher education institutions by using proportionate 
stratified random sampling. Number of sample from each institution is then identified as in the table 3 as follow.

Table 1

Sample Proportion of Each Institution

\begin{tabular}{llcc}
\hline No & \multicolumn{1}{c}{ Institution } & Population & Number of sample \\
\hline 1. & Universitas Andalas & 101 & $(101 / 243) 142=59$ \\
\hline 2. & $\begin{array}{l}\text { Politeknik Negeri } \\
\text { Padang }\end{array}$ & 97 & $(97 / 243) 142=57$ \\
\hline 3. & $\begin{array}{l}\text { Universitas Negeri } \\
\text { Padang }\end{array}$ & 45 & $(45 / 243) 142=26$ \\
Total & 243 & 142 \\
\hline \multicolumn{2}{l}{ Source: Primary data, processed 2019 }
\end{tabular}

In order to investigate the mediating effect of the adoption of social media usage, we use causal step analysis in terms of hierarchical regression as the method to test a set of conditions and/or protocols that need to be filled by a model to be treated as having the mediating variable. In order to have mediating effect, there are three conditions that need to be filled by each construct, which is [a] independent variables should significantly influence mediating variables $(a \neq 0) ;[b]$ independent variables should significantly influence dependent variables $(c \neq 0)$, and $[c]$ mediating variable should significantly influence dependent variable $(b \neq 0)$. Mediating effect occurs if the influence of independent variable to dependent variable is lower than the result of the third equation [c] compared with the first equation [a]. Variables of the study are defined based on the operational definition of each variable as the following table 1. 
Table 2

Operational Definition of Variables

\begin{tabular}{|c|c|c|c|}
\hline Variable & Concept of variable & Dimension & Indicators \\
\hline \multirow{9}{*}{$\begin{array}{l}\text { Performance } \\
\text { Expectancy }\end{array}$} & \multirow{9}{*}{$\begin{array}{l}\text { Performance } \\
\text { expectancy refers to } \\
\text { individuals' beliefs to } \\
\text { the use of a certain } \\
\text { system thart can assist } \\
\text { them to achieve a } \\
\text { better working } \\
\text { performance } \\
\text { (Venkatesh and Zhang, } \\
\text { 2010) }\end{array}$} & \multirow[t]{2}{*}{ Perception of use } & Product marketing \\
\hline & & & Market share \\
\hline & & $\begin{array}{l}\text { Extrinsic } \\
\text { motivation }\end{array}$ & Profit \\
\hline & & $\begin{array}{l}\text { Suitability of } \\
\text { tasks }\end{array}$ & $\begin{array}{l}\text { Easy to use in } \\
\text { business }\end{array}$ \\
\hline & & \multirow{3}{*}{$\begin{array}{l}\text { Relative } \\
\text { advantage }\end{array}$} & Effectivity \\
\hline & & & Efficient \\
\hline & & & Comfortability \\
\hline & & \multirow{2}{*}{$\begin{array}{l}\text { Performance } \\
\text { expectancy }\end{array}$} & Productivity \\
\hline & & & Performance \\
\hline \multirow[t]{3}{*}{$\begin{array}{l}\text { Perceived } \\
\text { Trust }\end{array}$} & \multirow{3}{*}{$\begin{array}{l}\text { Perceived trust refers } \\
\text { to the level of } \\
\text { customer's trust to the } \\
\text { quality and reliability } \\
\text { of products (Garbarino } \\
\text { \& Johnson, 2014). }\end{array}$} & $\begin{array}{l}\text { Disposition of } \\
\text { trust }\end{array}$ & Trust in usage \\
\hline & & $\begin{array}{l}\text { Structural } \\
\text { guarantee }\end{array}$ & Security of usage \\
\hline & & Trusting Belief & Trust in the usage \\
\hline \multirow{7}{*}{$\begin{array}{l}\text { Perceived } \\
\text { Risk }\end{array}$} & \multirow{7}{*}{$\begin{array}{l}\text { Perceived risk is an } \\
\text { uncertainty that is } \\
\text { faced by a society as } \\
\text { the consequence of } \\
\text { their decision (Im et al, } \\
\text { 2007). }\end{array}$} & Performance risk & Bad performance risk \\
\hline & & Financial risk & Risk of cost \\
\hline & & Time risk & Uneffectivity risk \\
\hline & & $\begin{array}{l}\text { Psychological } \\
\text { risk }\end{array}$ & Uncertainty risk \\
\hline & & Physical risk & Health risk \\
\hline & & Privacy risk & Security risk \\
\hline & & Overal risk & Business risks \\
\hline \multirow{6}{*}{$\begin{array}{l}\text { Social } \\
\text { Influence }\end{array}$} & \multirow{6}{*}{$\begin{array}{l}\text { The level of } \\
\text { individuals' beliefs that } \\
\text { view the interest of } \\
\text { others' trust will affect } \\
\text { the use of new system } \\
\text { (Venkatesh \& Morris, } \\
\text { 2010). }\end{array}$} & Subjective norms & Social pressure \\
\hline & & \multirow[t]{3}{*}{ Social factor } & $\begin{array}{l}\text { Social/institutional } \\
\text { support }\end{array}$ \\
\hline & & & $\begin{array}{l}\text { Support from } \\
\text { relatives }\end{array}$ \\
\hline & & & Social \\
\hline & & \multirow[t]{2}{*}{ Image } & Status and prestise \\
\hline & & & Trend \\
\hline \multirow{4}{*}{$\begin{array}{l}\text { Adoption } \\
\text { of Social } \\
\text { Media } \\
\text { Usage }\end{array}$} & \multirow{4}{*}{$\begin{array}{l}\text { The ability to exploit } \\
\text { the use a certain } \\
\text { technology, either } \\
\text { software or hardware } \\
\text { (Claar et al., 2014) }\end{array}$} & & Plan of usage \\
\hline & & & Intention of usage \\
\hline & & & Prediction of usage \\
\hline & & & Goals of usage \\
\hline \multirow{2}{*}{$\begin{array}{l}\text { The Depth } \\
\text { of social } \\
\text { media }\end{array}$} & \multirow{2}{*}{$\begin{array}{l}\text { How to take benefit of } \\
\text { the usage of social } \\
\text { media to communicate, }\end{array}$} & & Usage intensity \\
\hline & & & $\begin{array}{l}\text { Perceived } \\
\text { comfotability }\end{array}$ \\
\hline
\end{tabular}




\begin{tabular}{lll}
\hline Usage & $\begin{array}{l}\text { publish and to share } \\
\text { information about } \\
\text { products (Conole, et } \\
\text { al., 2008) }\end{array}$ & $\begin{array}{l}\text { Usage intensity for } \\
\text { business } \\
\text { commmunication }\end{array}$ \\
\cline { 2 - 2 } & $\begin{array}{l}\text { Usage intensity for } \\
\text { business publication }\end{array}$ \\
\cline { 2 - 2 } & $\begin{array}{l}\text { Usage intensity to } \\
\text { share information of } \\
\text { the product. }\end{array}$ \\
\hline
\end{tabular}

Source: Venkatesh \& Zhang, 2010; Garbarino \& Johnson, 2014; Im et al, 2007; Venkatesh \& Morris, 2010 and Conole, et al., 2008

The study uses online survey with google form as its data collection method. Respondents' confirmation to the online questionnaire was used as a proove that they understand about the questionnaire and have completely filled-up the questionnaire.

Structural Equation Model (SEM) based Partial Least Square (PLS) was used in this study to analyse data and information. Smart PLS 3.0 was then used as the main statistical software to support the data analysis. Following the protocol of SmartPLS 3.0, the study is conducted in three main data analysis, which consist of: [1] measurement of inner and outer models, which is futher conducted in two ways: (1a) measurement of convergent validity, and (1b) measurement of discriminant validity, [2] reliability test, which is undertaken in the form of: (2a) composite reliability measurement, and (2b) Cronbach Alpha, and [3] the test of hypotheses.

\section{RESULTS AND FINDINGS}

As a first task in this study, we are trying to highlights the characteristics of respondents of the study by dividing it into several characteristics, which are further exposed in crosstabulation tables $3,4,5$, and 6 as below. We first show profile of our respondents by considering their age and gender - and the result is shown in table 3. 
Table 3

Respondents Profile: Cross-Tabulation of Age and Gender

\begin{tabular}{|c|c|c|c|c|}
\hline & & \multicolumn{2}{|c|}{ Gender } & \multirow[t]{2}{*}{ Total } \\
\hline & & Male & Female & \\
\hline \multirow[t]{3}{*}{ Age } & $\leq 20$ years & 16 & 31 & 47 \\
\hline & 21-25 years & 43 & 52 & 95 \\
\hline & Total & 59 & 83 & 142 \\
\hline
\end{tabular}

Source: Primary data, processed (2019)

Our primary data reveals that respondents of the study were dominated by female students' entrepreneurs, in the age of 21 to 25 years old. As an effort to get isnights related to the information of the social media used by our respondents, we then profiled them based on the duration of the use of social media and the type of social media used by our respondents to support their business. This is the second task that we have done in giving a glance about our respondents' profile. The result is shown in the cross-tabulation as in the table 4.

Table 4

Respondents Profile: Cross-Tabulation of the Duration of Social Media Usage and the Type of Social Media Used for Business by Students' Entrepreneurs

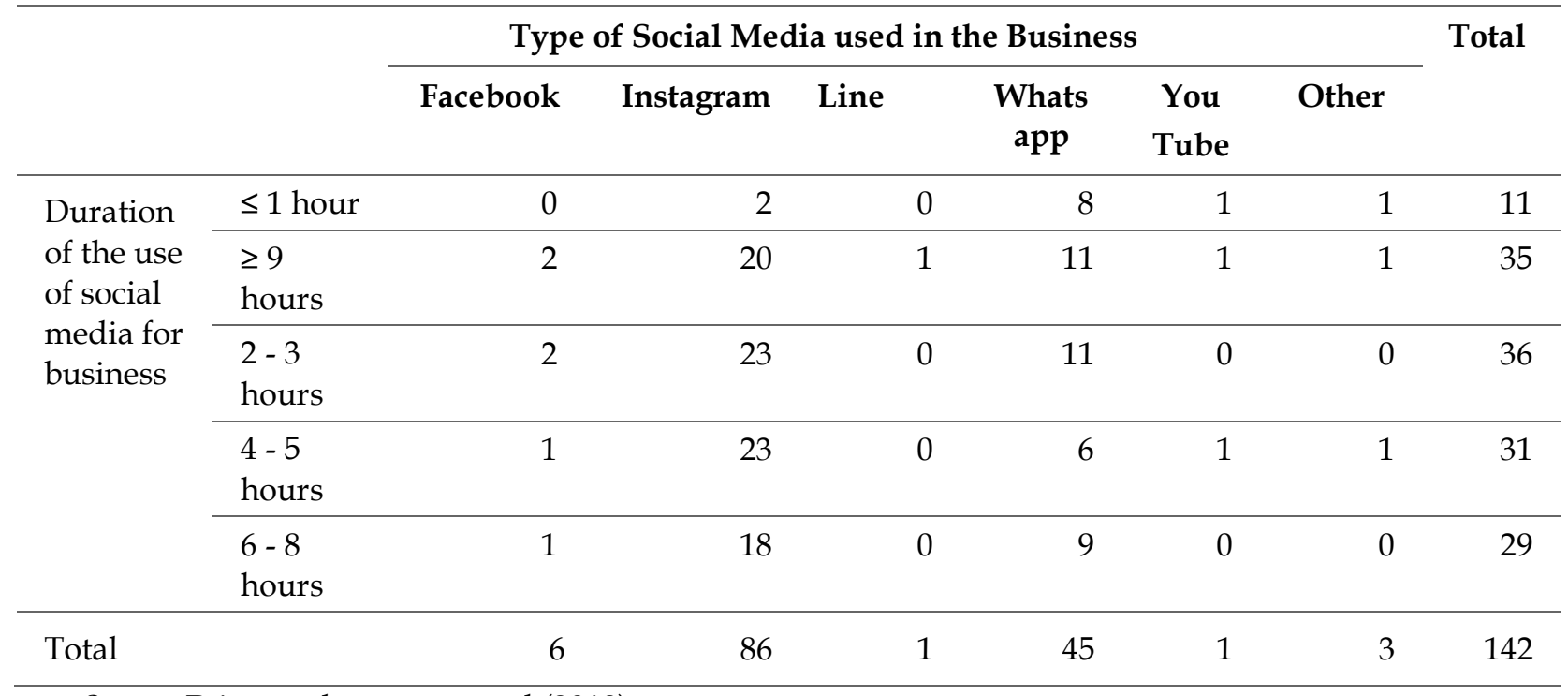

Source: Primary data, processed (2019)

Table 4 shows that the majority of respondents in this study $(60,6 \%)$ use Instagram as the social media platform for their business. From this type of respondents, the majority use 
Instagram fro business between 2-5 hours a day (in total, 46 respondents). YouTube and Line were the least used social media platform by respondents of the study.

The third respondents' profile that we would like to introduce is related to the type of devices used and the place, where respondents are accessing the social media for their business. This information is shown the table 7 below.

Table 5

Respondents Profile: Cross-Tabulation of the Devices used and the Place to Access the Social Media for Business

\begin{tabular}{llrrrrr}
\hline & \multicolumn{5}{c}{$\begin{array}{c}\text { Place to access the social media for } \\
\text { business }\end{array}$} & Total \\
\cline { 2 - 7 } & & Café & Campus & Other & House & \\
\hline Devices used & Other & 0 & 2 & 0 & 0 & 2 \\
\cline { 2 - 7 } & Laptop & 2 & 5 & 1 & 0 & 8 \\
\cline { 2 - 7 } & Smartphone & 2 & 28 & 14 & 87 & 131 \\
\cline { 2 - 7 } & Tablet & 0 & 0 & 0 & 1 & 1 \\
\hline Total & 4 & 35 & 15 & 88 & 142 \\
\hline
\end{tabular}

Source: Primary data, processed (2019)

In the third profile of respondents, we found that the majority of respondents accessed the social media platform by using smartphone as the main device, and house is the dominant place $(62 \%)$ when they want to use and access the platform.

One last respondent profile that we found is related to the monthly earning from business and the business field of each respondent. The finding is shown in the cross-tabulation table as in the table 6 below. 
Table 6

Respondents Profile: Cross-Tabulation of the Monthly Business Earning (in IDR) and Business Fields

\begin{tabular}{|c|c|c|c|c|c|c|c|c|c|}
\hline & & \multicolumn{7}{|c|}{ Field of Business } & \multirow{2}{*}{$\begin{array}{c}\text { Tot } \\
\text { al }\end{array}$} \\
\hline & & $\begin{array}{c}\text { Agro } \\
- \\
\text { busi } \\
\text { ness }\end{array}$ & $\begin{array}{l}\text { Distribu } \\
\text { tion }\end{array}$ & $\begin{array}{l}\text { Fashi } \\
\text { on }\end{array}$ & $\begin{array}{c}\text { Ser } \\
\text { vice }\end{array}$ & $\begin{array}{l}\text { Culi } \\
\text { nary }\end{array}$ & $\begin{array}{c}\text { Manufact } \\
\text { ure }\end{array}$ & $\begin{array}{c}\text { Mercha } \\
\text { ndise }\end{array}$ & \\
\hline \multirow{6}{*}{$\begin{array}{l}\text { Monthly } \\
\text { business } \\
\text { earning }\end{array}$} & $\begin{array}{r}< \\
1,000 \\
000\end{array}$ & 3 & 2 & 19 & 15 & 26 & 3 & 8 & 76 \\
\hline & $\begin{array}{r}>10,0 \\
00,00 \\
0\end{array}$ & 0 & 0 & 0 & 1 & 0 & 0 & 0 & 1 \\
\hline & $\begin{array}{r}1,000 \\
001- \\
3,000 \\
000\end{array}$ & 1 & 3 & 7 & 13 & 21 & 1 & 6 & 52 \\
\hline & $\begin{array}{r}3,000 \\
001- \\
5,000 \\
000\end{array}$ & 1 & 0 & 0 & 4 & 1 & 0 & 0 & 6 \\
\hline & $\begin{array}{c}5,000, \\
001- \\
10,00 \\
0,000\end{array}$ & 0 & 0 & 2 & 2 & 3 & 0 & 0 & 7 \\
\hline & Total & 5 & 5 & 28 & 35 & 51 & 4 & 14 & 142 \\
\hline
\end{tabular}

Source: Primary data, processed (2019)

Table 6 indicates that respondents who have culinary business are the dominant respondents in this study (51 respondents). In terms of monthly business earning, respondents revealed that their business can earn in the range of <IDR. 1,000,000 to >IDR 10,000,000. However, the majority of respondents told us that their business monthly earning is only <IDR $1,000,000$ (76 respondents).

As the main step in the data analysis, we first conducted measurement of outer model to check the validity and realiability of the data by considering the convergent and discriminant validity. Indicators of the study are valid if the value of outer loading is higher than 0.7. However, indicators still consider as valid even if they have the value between 0.5 and 0.7 - in the condition that the AVE and communality are higher than 0.5. Using the principle and protocol of convergent validity, we found that every indicator of variables in this study is valid 
as the value of indicator in the outer loading is higher than 0.5. The detailed result of the outer model in this study is shown in table 7.

Table 7

Outer Loading of Indicators

Adoption of Depth-use Performance Perceived Perceived Social the use of of social expectancy risks $(X 3)$ trust $(X 2)$ influence social media media (Y) (X1)

(X5)

\begin{tabular}{llll}
\hline ASM1 & 0.922 & & \\
\hline ASM2 & 0.943 & & \\
\hline ASM3 & 0.936 & & \\
\hline ASM4 & 0.805 & 0.895 & \\
\hline DSM1 & 0.923 & & \\
\hline DSM2 & 0.887 & & \\
\hline DSM3 & 0.904 & 0.904 & \\
\hline DSM4 & 0.917 & 0.883 & \\
\hline DSM5 & & 0.858 & \\
\hline PE1 & & 0.875 & \\
\hline PE2 & & 0.868 & \\
\hline PE3 & & 0.916 & \\
\hline PE4 & & 0.832 & \\
\hline PE5 & & 0.841 & \\
\hline PE6 & & & \\
\hline PE7 & & & \\
\hline PE8 & & & \\
\hline PE9 & & & \\
\hline PR1 & & & \\
\hline PR2 & & & \\
\hline PR3 & & & \\
\hline PR4 & & & \\
\hline PR5 & & & \\
\hline
\end{tabular}


Andalas Management Review, Vol. 3 No. 1, 2019

\begin{tabular}{lll}
\hline PR6 & 0.785 & \\
\hline PR7 & 0.857 & 0.854 \\
\hline PT1 & 0.872 \\
\hline PT2 & 0.916 \\
\hline PT3 & 0.776 \\
\hline PT4 & 0.929 \\
\hline PT5 & 0.891 & \\
\hline PT6 & & 0.802 \\
\hline SI1 & & 0.841 \\
\hline SI2 & & 0.873 \\
\hline SI3 & & 0.921 \\
\hline SI4 & & 0.841 \\
\hline SI5 & & 0.852 \\
\hline SI6 & & 0.838 \\
\hline SI7 & & 0.814 \\
\hline SI8 & & \\
\hline
\end{tabular}

Source: primary data, processed (2019)

Remarks:

$\begin{array}{llll}\text { ASM } & =\text { Adoption of Social Media Usage } & \text { PR } & =\text { Perceived Risk } \\ \text { DSM } & =\text { Depth of Social Media Usage } & \text { SI } & =\text { Sosial Influence } \\ \text { PE } & =\text { Perfomance Expectancy } & \text { PT } & =\text { Perceived Trust }\end{array}$

Discriminant validity in SEM-PLS of the study is shown in table 10. 
Table 8

Cross Loading Value of Indicators

\begin{tabular}{|c|c|c|c|c|c|c|}
\hline & $\begin{array}{l}\text { Adoption of } \\
\text { Social Media } \\
\text { Usage (X5) }\end{array}$ & $\begin{array}{c}\text { Depth-Usage } \\
\text { of Social } \\
\text { Media (Y) }\end{array}$ & $\begin{array}{c}\text { Perceive } \\
\text { d risk } \\
\text { (X3) }\end{array}$ & $\begin{array}{c}\text { Perceived } \\
\text { trust } \\
(\mathrm{X} 2)\end{array}$ & $\begin{array}{c}\text { Performance } \\
\text { expectancy } \\
\text { (X1) }\end{array}$ & $\begin{array}{l}\text { Social } \\
\text { influence } \\
(X 4)\end{array}$ \\
\hline ASM1 & 0.922 & 0.614 & -0.156 & 0.685 & 0.650 & 0.697 \\
\hline ASM2 & 0.943 & 0.643 & -0.162 & 0.718 & 0.728 & 0.722 \\
\hline ASM3 & 0.936 & 0.661 & -0.156 & 0.679 & 0.679 & 0.734 \\
\hline ASM4 & 0.805 & 0.642 & -0.078 & 0.579 & 0.591 & 0.621 \\
\hline DSM1 & 0.601 & 0.895 & -0.030 & 0.588 & 0.591 & 0.555 \\
\hline DSM2 & 0.648 & 0.923 & -0.052 & 0.597 & 0.605 & 0.627 \\
\hline DSM3 & 0.601 & 0.887 & -0.051 & 0.566 & 0.600 & 0.523 \\
\hline DSM4 & 0.694 & 0.904 & -0.053 & 0.550 & 0.601 & 0.600 \\
\hline DSM5 & 0.656 & 0.917 & -0.070 & 0.556 & 0.567 & 0.564 \\
\hline PE1 & 0.668 & 0.583 & -0.021 & 0.764 & 0.904 & 0.620 \\
\hline PE2 & 0.649 & 0.586 & -0.045 & 0.753 & 0.883 & 0.607 \\
\hline PE3 & 0.615 & 0.574 & -0.037 & 0.722 & 0.858 & 0.617 \\
\hline PE4 & 0.651 & 0.571 & -0.080 & 0.756 & 0.875 & 0.638 \\
\hline PE5 & 0.654 & 0.599 & -0.059 & 0.750 & 0.868 & 0.641 \\
\hline PE6 & 0.697 & 0.569 & -0.073 & 0.846 & 0.916 & 0.673 \\
\hline PE7 & 0.622 & 0.534 & -0.088 & 0.749 & 0.832 & 0.596 \\
\hline PE8 & 0.604 & 0.538 & 0.009 & 0.798 & 0.841 & 0.546 \\
\hline PE9 & 0.594 & 0.576 & -0.012 & 0.829 & 0.861 & 0.574 \\
\hline PR1 & -0.179 & -0.030 & 0.884 & -0.060 & -0.093 & -0.015 \\
\hline PR2 & 0.034 & 0.056 & 0.674 & -0.003 & -0.002 & 0.081 \\
\hline PR3 & -0.101 & -0.049 & 0.854 & -0.075 & -0.071 & -0.026 \\
\hline PR4 & -0.115 & -0.081 & 0.880 & -0.076 & -0.021 & -0.017 \\
\hline PR5 & -0.081 & 0.011 & 0.795 & -0.006 & 0.038 & 0.014 \\
\hline PR6 & -0.003 & -0.005 & 0.785 & 0.020 & 0.035 & 0.068 \\
\hline PR7 & -0.054 & -0.027 & 0.857 & -0.021 & 0.015 & -0.010 \\
\hline PT1 & 0.615 & 0.539 & -0.097 & 0.854 & 0.809 & 0.592 \\
\hline PT2 & 0.628 & 0.561 & -0.074 & 0.872 & 0.779 & 0.625 \\
\hline PT3 & 0.695 & 0.583 & -0.088 & 0.916 & 0.803 & 0.666 \\
\hline PT4 & 0.535 & 0.447 & -0.026 & 0.776 & 0.652 & 0.475 \\
\hline PT5 & 0.722 & 0.601 & -0.062 & 0.929 & 0.801 & 0.688 \\
\hline PT6 & 0.658 & 0.565 & -0.007 & 0.891 & 0.808 & 0.628 \\
\hline SI1 & 0.611 & 0.423 & -0.008 & 0.563 & 0.545 & 0.802 \\
\hline SI2 & 0.564 & 0.446 & -0.028 & 0.527 & 0.510 & 0.841 \\
\hline SI3 & 0.645 & 0.509 & -0.078 & 0.609 & 0.605 & 0.873 \\
\hline SI4 & 0.747 & 0.612 & -0.052 & 0.661 & 0.657 & 0.921 \\
\hline SI5 & 0.615 & 0.532 & -0.019 & 0.580 & 0.610 & 0.841 \\
\hline
\end{tabular}




\begin{tabular}{llrrrrr}
\hline SI6 & 0.706 & 0.588 & -0.013 & 0.615 & 0.634 & $\mathbf{0 . 8 5 2}$ \\
\hline SI7 & 0.635 & 0.580 & 0.016 & 0.595 & 0.597 & $\mathbf{0 . 8 3 8}$ \\
\hline SI8 & 0.666 & 0.580 & 0.012 & 0.613 & 0.597 & $\mathbf{0 . 8 1 4}$ \\
\hline
\end{tabular}

Source: primary data, processed (2019)

Remarks:

$\begin{array}{llll}\text { ASM } & =\text { Adoption of Social Media Usage } & \text { PR } & =\text { Perceived Risk } \\ \text { DSM } & =\text { Depth of Social Media Usage } & \text { SI } & =\text { Sosial Influence } \\ \text { PE } & =\text { Perfomance Expectancy } & \text { PT } & =\text { Perceived Trust }\end{array}$

Table 8 suggests that the correlation from constructs' indicators have bigger values compared with the correlation of other constructs. All indicators of the study are then viewed as having filled-up the criteria of the discriminant validity. Using other methods to investigate the validity of constructs in this study, which are: [a] Average Variance Extracted-AVE, and [b] the square root of the average of AVE, we also found that all constructs used in the study has filled the criteria for discriminant validity. AVE analysis of the constructs in this study shows the value of more than 0.5 for all constructs - which means that all constructs of this study are valid. Detailed result of AVE analysis is shown in the table 9 below.

Table 9

Average Veriance Extracted (AVE)

Variables
The Value of Average

Variance Extracted (AVE)

\begin{tabular}{cc}
\hline The adoption of social media usage & 0.816 \\
\hline The depth usage of social media & 0.819 \\
\hline Perceived risks & 0.675 \\
\hline Perceived trust & 0.765 \\
\hline Performance expectancy & 0.759 \\
\hline Social influence & 0.720
\end{tabular}

Source: primary data, processed (2019) 
In the Square Root of Average of AVE, it is found that the value for each contruct is bigger compared with the correlation between construct - which further means that each construct has sufficient discriminant validity. Detailed result of Square Root of Average for each construct is shown in table 10 below.

\section{Table 10}

Latent Variable Correlation (Square Root of Average of AVE)

\begin{tabular}{|c|c|c|c|c|c|c|}
\hline & $\begin{array}{l}\text { The adoption } \\
\text { of social media } \\
\text { usage }(X 5)\end{array}$ & $\begin{array}{l}\text { The depth- } \\
\text { usage of social } \\
\text { media }(Y)\end{array}$ & $\begin{array}{l}\text { Perceived } \\
\text { risk }(\mathrm{X} 3)\end{array}$ & $\begin{array}{l}\text { Perceived } \\
\text { trust }(X 2)\end{array}$ & $\begin{array}{l}\text { Performance } \\
\text { expectancy } \\
(\mathrm{X} 1)\end{array}$ & $\begin{array}{l}\text { Social } \\
\text { influen } \\
\text { ce }(X 4)\end{array}$ \\
\hline $\begin{array}{l}\text { The adoption of } \\
\text { social media usage } \\
\text { (X5) }\end{array}$ & 1.000 & & & & & \\
\hline $\begin{array}{l}\text { The depth usage of } \\
\text { social media (Y) }\end{array}$ & 0.708 & 1.000 & & & & \\
\hline Perceived risk (X3) & -0.154 & -0.057 & 1.000 & & & \\
\hline $\begin{array}{l}\text { Perceived trust } \\
\text { (X2) }\end{array}$ & 0.738 & 0.631 & -0.068 & 1.000 & & \\
\hline $\begin{array}{l}\text { Performance } \\
\text { expectancy (X1) }\end{array}$ & 0.735 & 0.655 & -0.052 & 0.888 & 1.000 & \\
\hline $\begin{array}{l}\text { Social influence } \\
\text { (X4) }\end{array}$ & 0.769 & 0.635 & -0.025 & 0.705 & 0.704 & 1.000 \\
\hline
\end{tabular}

Source: primary data, processed (2019)

As the second step of data analysis in this study, we conducted reliability test to measure the accuracy and precision of the measurement tool used in the study. Reliability is determined by the value of Cronbach's Alpha and Composite Reliability for each block of indicators. As a rule, the values of Cronbach's Alpha and Composite Reliability are considered high if they are bigger than 0.7 - but are still acceptable if they are in between of $0.6-0.7$. We view that the indicators of this study are reliable as we found that their value are higher than 0.7 (Cronbach's Alpha and Composite Reliability). Detailed results of Composite Reliability and Coranbach's Alpha of this study can be seen in the following table 11. 
Table 11

Measurement of Reliability Test: Composite Reliability dan Cronbach Alpha

\begin{tabular}{ccc} 
Variables & $\begin{array}{c}\text { Cronbach's } \\
\text { Alpha }\end{array}$ & $\begin{array}{c}\text { Composite } \\
\text { Reliability }\end{array}$ \\
\hline The adoption of social media usage & 0.923 & 0.946 \\
\hline The depth-usage of social media & 0.945 & 0.958 \\
\hline Perceived risk & 0.932 & 0.935 \\
\hline Pwerceived trust & 0.938 & 0.951 \\
\hline Performance expectancy & 0.960 & 0.966 \\
\hline Social influence & 0.944 & 0.954 \\
\hline
\end{tabular}

Source: primary data, processed (2019)

The next step in data analysis of this study is to test the structural model of the study (inner model) which aims at idetifiying the strengths of relationship between independent and dependent vairables. We are using R-Square $\left(R^{2}\right)$ analysis to test the inner model of this study to measure the substantial influence of a certain latent independent variable to latent dependent variable. As a rule, a structural model which has the value of $\mathrm{R}^{2}=0.67$ is identified as the strong relationship, $\mathrm{R}^{2}=0.33$ as the moderate relationship and $\mathrm{R}^{2}=0.19$ as the weak relationship. Results of the $\mathrm{R}^{2}$ in the research model in this study is shown in the following table 12.

Table 12

Results of the Inner Model Analysis (R²)

Variables $\quad \mathrm{R}^{2}$

\begin{tabular}{|c|c|}
\hline Perceived risk & \\
\hline Perceived trust & \\
\hline \multicolumn{2}{|l|}{ Performance expectancy } \\
\hline \multicolumn{2}{|l|}{ Social influence } \\
\hline The adoption of social media usage & 0.690 \\
\hline The depth-usage of social media & 0.548 \\
\hline
\end{tabular}

Table 12 of this study above suggests us that the $\mathrm{R}^{2}$ for the use of social media the business platform among student entrepreneurs In Padang is 0.690. This means that the 
variance of performance expectancy, perceived trust, perceived risk and social influence can explain the adoption of the use of social media (with the value of $69 \%$ ). This further implies that there is a strong relationship between the variable of performance expectancy, perceived trust, perceived risk and social influence to the adoption of the use of social media by our samples meanwhile the rest $31 \%$ is influenced by other variables which are not considered in this study.

In the depth use of social media as the business platform used by students entrepreneurs, we found the value of $\mathrm{R}^{2}=0.548$, which means that the variance of performance expectancy, perceived trust, perceived risk and social influence can explain the depth use of social media for $54.8 \%$ - and this relationship is considered as a moderate relationship. The rest $46.2 \%$ of the influence is coming from other variables which are not considered in this study.

Based on the analysis regarding the measurement of the inner model of this study, we then develop the Structural Model for this study, which is further drawn in the following figure 2. 


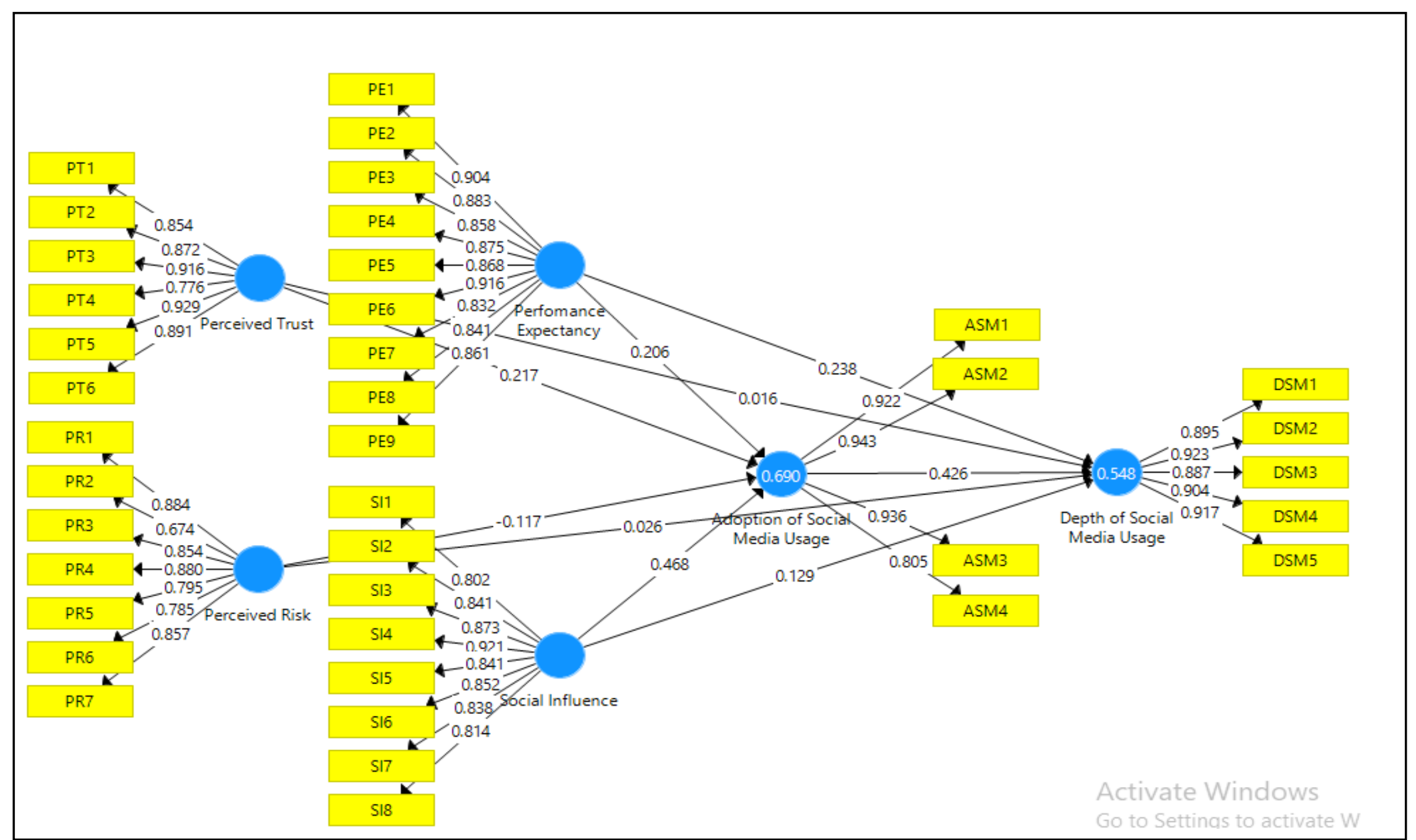

Figure 2. Structural Model of the Variance of Performance Expectancy, Perceived Trust, Perceived Risk, Social Influence, the Adoption of Social Media Usage and the Depth Usage of Social Media among Students Entrepreneurs Source: Output SmartPLS 3.0, (2019) 
As the basis to test hypotheses of this study, we understand that PLS uses nonparametric test to determine the significance of path coefficient. Therefore, the value of $t(t-$ statistics) produced from algorithm bootstrapping in SmartPLS will be used to determine whether the hypotheses is accepted or rejected. Hypotheses will be accepted if the value of $t-$ statistics is higher than the value of $t$-table, which is 1.96. The result of hypotheses testing of this study can further be seen in the path coefficient table as follow.

Table 13

Hypotheses Testing in form of Path Coefficient

\begin{tabular}{|c|c|c|c|c|c|c|}
\hline Variables & $\begin{array}{l}\text { Original } \\
\text { Sample } \\
(\mathrm{O})\end{array}$ & $\begin{array}{l}\text { Sample } \\
\text { Mean } \\
(\mathrm{M})\end{array}$ & $\begin{array}{l}\text { Standard } \\
\text { Deviation } \\
(\text { STDEV) }\end{array}$ & $\begin{array}{c}\mathrm{T}- \\
\text { Statistics }\end{array}$ & $\begin{array}{c}\text { P- } \\
\text { Value }\end{array}$ & Meaning \\
\hline $\begin{array}{l}\text { Performance } \\
\text { expectancy } \rightarrow \text { the } \\
\text { adoption of social } \\
\text { media usage }\end{array}$ & 0.206 & 0.187 & 0.105 & 1.963 & 0.050 & $\begin{array}{c}\text { Significant } \\
\text { Hypotheses } \\
\text { Accepted }\end{array}$ \\
\hline $\begin{array}{l}\text { Perceived trust } \rightarrow \text { the } \\
\text { adoption of social } \\
\text { media usage }\end{array}$ & 0.217 & 0.218 & 0.103 & 2.114 & 0.035 & $\begin{array}{c}\text { Significant } \\
\text { Hypotheses } \\
\text { Accepted }\end{array}$ \\
\hline $\begin{array}{l}\text { Perceived risk } \rightarrow \text { the } \\
\text { adoption of social } \\
\text { media usage }\end{array}$ & -0.117 & -0.089 & 0.077 & 1.522 & 0.129 & $\begin{array}{c}\text { In-significant } \\
\text { Hypotheses } \\
\text { Rejected }\end{array}$ \\
\hline $\begin{array}{l}\text { Social influence } \rightarrow \text { the } \\
\text { adoption of social } \\
\text { media usage }\end{array}$ & 0.468 & 0.474 & 0.082 & 5.734 & 0.000 & $\begin{array}{c}\text { Significant } \\
\text { Hypotheses } \\
\text { Accepted }\end{array}$ \\
\hline $\begin{array}{l}\text { the adoption of social } \\
\text { media usage } \rightarrow \text { the } \\
\text { depth usage of social } \\
\text { media }\end{array}$ & 0.426 & 0.402 & 0.155 & 2.749 & 0.006 & $\begin{array}{c}\text { Significant } \\
\text { Hypotheses } \\
\text { Accepted }\end{array}$ \\
\hline
\end{tabular}

Source: primary data, processed (2019)

Table 13 suggests that the variables of performance expectancy, perceived trust and social influence have positively and significantly influenced the adoption of the use of social media by students entrepreneurs in Padang. This can be seen by the coefficient of original sample which shows the values of 0.206 (for performance xpectancy), 0.217 (for perceived trust) and 0.468 (for social influence). T-statistics for those three variables also show a bigger value rather that t-table (1.960). The T-statistics for each variable is: 1.963 (for performance expectancy), 2.114 (perceived trust) and 5.734 (social influence). Values from both [1] the coffiecient of original sample, and [2] T-statistics of the three variables (performance expectancy, perceived trust and social influence) imply that the hypotheses for all those three variables are accepted. However, perceived risk is found to have negative and 
insignificant influence to the adoption of social media usage - and therefore, the hypotheses is rejected.

The last task in this study is to identify whether there is a mediating effect of the adoption of social media usage to the depth usage of social media by students entrepreneurs in the context of study. For this purpose, we conducted the mediating effect test by using causal step analysis specifically hierarchical regression analysis in which particular statistical protocol was undertaken. The result of mediating effect test using the causal step analysis in this study is further shown in table 14 below. 
Table 14

The Result of Mediating Effect Test using Causal Step Alalysis

Coefficient p-value Requirement for next Remark steps

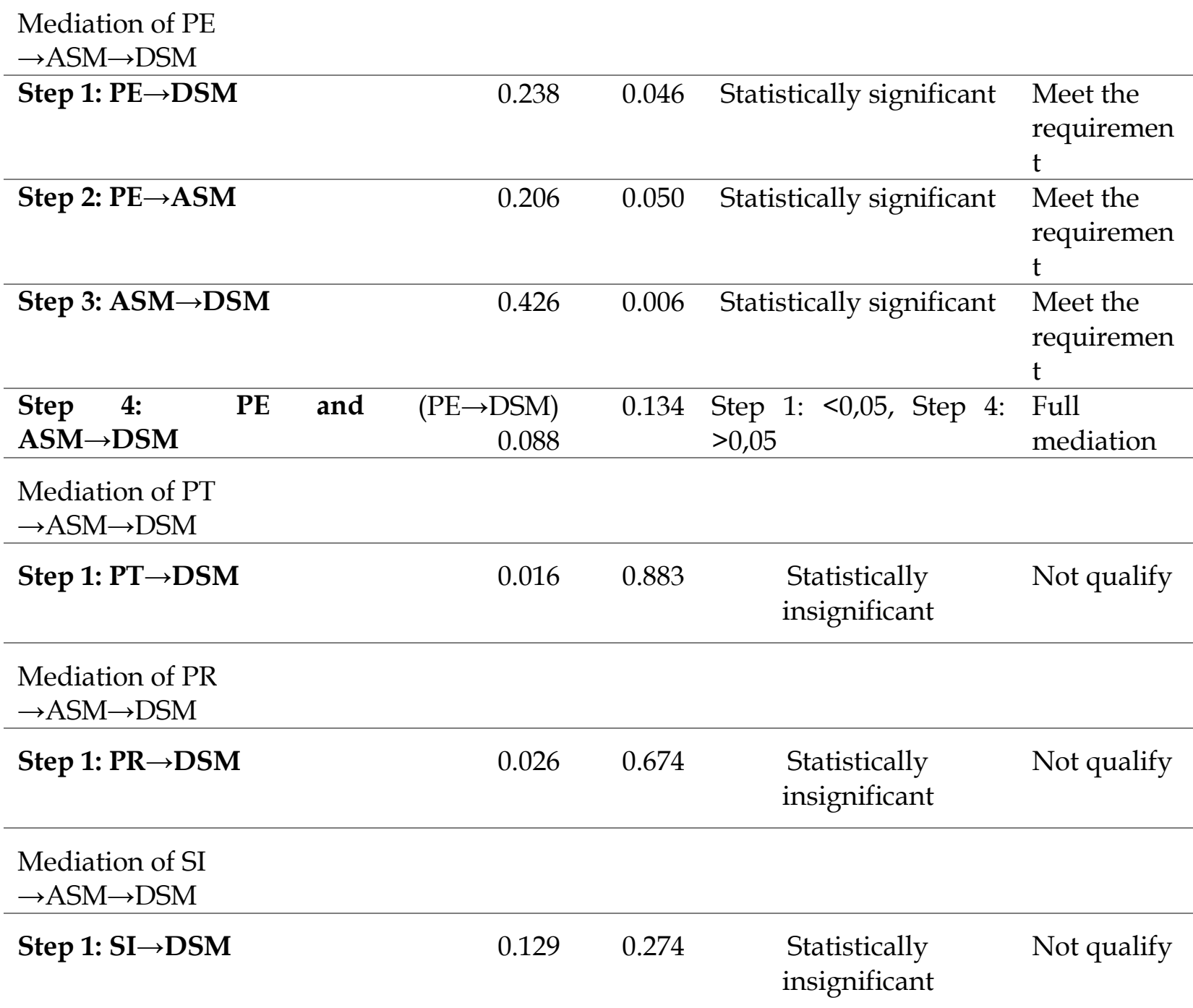

Source: primary data, processed (2019)

Remarks:

$\begin{array}{llll}\text { ASM } & =\text { Adoption of Social Media Usage } & \text { PR } & =\text { Perceived Risk } \\ \text { DSM } & =\text { Depth of Social Media Usage } & \text { SI } & =\text { Sosial Influence } \\ \text { PE } & =\text { Perfomance Expectancy } & \text { PT } & =\text { Perceived Trust }\end{array}$

From table 14, we can see that in the mediation of PE $\rightarrow$ ASM $\rightarrow$ DSM, the coefficients of every variable are bigger than the p-value in each step of analysis in causal step analysis. Therefore, we conclude that there is the presence of full mediating effect of the adoption of social media usage in the relationship between performance expecatancy and the depth usage of social media as the business platform among students entrepreneurs in the context 
of study. From table 14, we also know that the mediation effect of PT $\mathrm{ASM} \rightarrow \mathrm{DSM}, \mathrm{PR}$

$\mathrm{ASM} \rightarrow \mathrm{DSM}$ and SI $\rightarrow \mathrm{ASM} \rightarrow \mathrm{DSM}$ do not qualify for further steps in causal step analysis. That is why of of those three models cannot provide full mediating effect in the relationship between all variables. As three out of four models to investigate the mediating effect of the adoption of social media usage in the relationship between performance expectancy, perceived trust, perceived risk, social influence and the depth usage of social media do not qualify for causal step analysis, we can then conclude that the sixth hypotheses of this study is not supported.

\section{DISCUSSION}

As has been found, samples of the study believe that by adopting the use of social media for their business will increase their business performance. This further means that our samples believe that the higher performance expectancy is, then the bigger the intention to adopt social media as their business platform is. If we relate this finding with profile of our respondents which is dominated by those who are under the age of 25 years old, we can consider that this type of people typically has a big intention to achieve the positive things for their future. According to this type of people, the future performance expectancy in business can be achieved if they can take benefits from the use of social media as a mean to communicate, to share information and even, to operate the business. This finding also implies that students entrepreneurs tend to set their own business goals [i.e. by clearly stating the future expectancies] first before they started their business. This goal will then be followed by several actions in business, which one of it is the use of social media. In a broader scope, this finding proves that students entrepreneurs in the context of study has already had a strategic thinking and planning which is a very critical point and very useful for their business. As we understand, the ability to plan and think strategically is one of the prerequisites for entrepreneurs, if they want to establish and maintain their competitive advantage so that their business can stay longer in the industry. The ability to set future performance expectancy through the goal setting will also a sign of the level of maturity from students entrepreneurs in the context of our study.

This finding is also in line with the findings that the use of social media will assist people in publishing their business (Qualman, 2009), will provide significant business support and benefits, (Hite and Hesterly, 2001), social interaction and behavioural intention to learn. In a more recent and straight result, finding of this study is similar to what Noorshella et al., (2017) have found. They mentioned that the performance expectancy of 
students entrepreneurs in Malaysia will lead them to adopt the use of social media as their business platform.

In terms of trust, finding of the study shows the belief from students entrepreneurs that the depth usage of social media as the business platform will positively affect their business. As the nature of our samples which can be categorized as 'millenials' - the use of social media is a normal thing and even, the demand for their daily life. Social media is not only be used to communicate but has spreaded to many activities in their life, including as the supporting media for businesses. As a new kind of technologies and as Howcroft et al., (2002), people will not use social media until they believe that the use of that technology will benefit them. In the context of our study, this means that students entrepreneurs will believe to use social media as the platform to support their business if it can benefit them personally and further, their business. Noorshella et al., (2017) in their study also found the similar thing among student entrepreneurs in Malaysia who said that perceived trust from student entrepreneurs to social media will lead them adopt the use of social media for the interest of their business.

In regards of perceived risk to adopt social media usage, our study found that the higher the risk perceived by student entrepreneurs when using the social media will not necessarily influence their intention to adopt the use of social media for their business. This implies that student entrepreneurs in the context of study are considering the high risks of using the social media, but they will not accept the negative consequence of using social media in the short-term period for their business. This finding also shows us that student entrepreneurs in the context of study are actually not brave enough to face risks in business and further, still have higher fear of failure in operating their business. We view that student entrepreneurs as having a certain psychological constraint related to failure. As the business is usually the students' first business, then the rate of fear of failure among them is believed, higher. This situation has pushed them to avoid the risk as much as they can, in every part of their business. As Shambare et al., (2013) found, fear of failure has been a major psychological situation that needs to be faced by students and is the reason of why they are having less interest to start their business. However, we realize that the context of study and cultural background matter. As our study was undertaken with student entrepreneurs in one city in Indonesia where the Minangkabau ethnic is the major ethnicity, there will be the presence of different psycho-cultural background between one ethnic to other enthnicities. As Rahman, et al., (2019) cited, the different psycho-cultural beckground between ethnicities in regions will consequence the creation and the level of entrepreneurial climate among 
them. This will further derive to the psychological situation of individuals in one ethnic in viewing entrepreneurship, in which one ethnic can have more fear of failure to start a business compared with other ethnicities.

We also consider social influence as a factor that can influence student entrepreneurs in adopting the social media usage for their business platform. The finding of our study shows that social influence significantly and positively influences student entrepreneurs in adopting the usage of social media as their business platform. This implies that support and motivation from the closest relative and other parties in students' social environment (mainly families, friends, mentors and partners) will be the trigger for them to use social media as their business platform. The fact of the development in business environment which has boosted the use of social media either by small, medium and larger enterprises to reach a broader and more global market is also a particular support and motivation for them to use the social media as the business platform. In the context of our study, the respondent is dominated by female student entrepreneurs. Since females are often more sensitive to accept other's opinion, this is why social environment of females is more effective to influence their intention to use a new tehcnnology, i.e. social media as the business platform. The presence of family and mentor is also viewed to have a positive and significant influence to student entrepreneurs to adopt the use of social media. As Rahman and Day (2015), older parties usually have bigger roles in influencing younger individuals to make decisions in business, especially decisions which are related to the use of a new technology.

The fifth finding of our study shows that student entrepreneurs who adopt the use of social media as their business platform will use the social media deeply. This means that once a student entrepreneur uses the social media for his/her business, then he/she will normally use it continuously and will further use it with determination in his/her business. This also means that the more student entrepreneurs expose to social media is, then the more possibility for them to use it with higher determination. We believe that this condition is a reflection of the demographic characteristic of our sample with regards of their age. Since our samples are student entrepreneurs who are in the age of below 25 years old, then the depth usage of social media in their daily life including for business purposes is not something that is surprising

\section{SUMMARY AND IMPLICATION}

As the findings, this study found that performance expectancy, perceived trust and social influence have significantly influenced the adoption of social media usage by student 
entrepreneurs in the context of study, while perceived risk brings negative and significant influence. It further found that the adoption of social media usage by student entrepreneurs will significantly and positively influence the depth usage of social media as the business platform amog student entrepreneurs. However, the study found that the adoption of social media usage by student entrepreneurs cannot create mediating effect in the relationship between performance expectancy, perceived trust, perceived risk, social influence and the depth usage of social media as the business platform among student entrepreneurs.

This study believes that age of samples together with their psychological circumstance matter. Since samples of this study are merely students who are in the age of 17-25 years old, then this demographic characteristic has brought significant contribution to our findings. As we know, people who are in this age range, are very easy to get exposed to the social media in their life - and this situation impacts to the choice of business platform that they use. However, as other nascent entrepreneurs, our samples tend to avoid risks in businesses as much as they can, and this also implies when they are using the social media as their business platform.

This study also found that student entrepreneurs prefer to choose and use Instagram and Whatsapp as the social media for their business platform and they merely use smartphone as the device to access that social media. This study implies that in the future, student entrepreneurs will always prefer to use social media as the business platfrom for their business. Therefore, stakeholder interventions to encourage and promote the use of information technology among student entrepreneurs and to provide an easy and a reachable internet access, as well as lowering the internet tariff for businesses belong to nascent entrepreneurs will a reasonable choice to support student entrepreneurs. Stakeholder intervention can also be in terms of assisting the development of a special designated social media developed by local nascent information technology entrepreneur to be used by student entrepreneurs as their business platform.

\section{REFERENCES}

APJII (2017). Infografis Hasil survey 2017: Penetrasi \& Perilaku Pengguna Internet Indonesia. http://www.teknopreneur.com.

Baghai, M., Coley, S., \& White, D. (2000). The Alchemy of Growth: Practical insights for building the enduring enterprise. New York, NY: Basic Books.

Bailetti, T. (2011). Fostering student entrepreneurship and university spin-off companies. Technology Innovation Management Review, Vol. 1, pp. 7-12. 
Brown, J., Broderick, A. \& Lee, N. (2007). "Word of mouth communication within online communities: Conceptualizing the online social network." Journal of Interactive Marketing. Vol. 21, No. 3, pp. 2-20

Carlsson, C., et al. (2006), Adoption of mobile devices/services - searching for answers with the UTAUT, Proceedings of the 39th Annual Hawaii International Conference on System Sciences (HICSS'06), IEEE Portal: IEEE Xplore Digital Library.

Claar, C., Dias, L. P., \& Shields, R. (2014). Student acceptence of learning management systems: a study on demographics. Issues in Information Systems, Vol. 15, No.1, pp.409417.

Conole, G., et al. (2008). Disruptive technologies, pedagogical innovation: What's new? Findings from an in-depth study of students' use and perception of technology. Computers \& Education, Vol. 50, No. 2, pp. 511-524.

Davis, F.D. (1989). Perceived Usefulness, Perceived Ease of Use dan Acceptance of Information System Technology. MIS Quarterly, Vol. 13, No. 3, pp. 319-339.

Davis, E.D., Bagozzi, R.P. \& Warshaw, P. (1992). “Extrinsic and intrinsic motivation to use computers in the workplace.", Journal of Applied Social Psychology, Vol. 24, No. 14, pp. 1111-1132.

Ellison, N. B., Steinfield, C., \& Lampe, C. (2007). "The benefit of Facebook "friends": Social capital and college students use of online social network sites.", Journal of ComputerMediated Communication, Vol. 12, No. 4, pp. 1143-1168.

Escobar-Rodríguez, T., Carvajal-Trujillo, E., \& Monge-Lozano, P. (2014). “Factors that influence the perceived advantages and relevance of Facebook as a learning tool: An extension of the UTAUT.", Australasian Journal of Educational Technology, Vol. 30, No. 2, pp. 136-151.

Evans, D. (2010). Social Media Marketing - The Next Generation of Business Engagement. Wiley Publishing Inc. Indiana

Featherman, M.S. \& Pavlou, P.A. (2003), "Predicting e-services adoption: a perceived risk facets perspective.", International Journal of Human Computer Studies, Vol. 59, No. 4, pp. 451-474.

Foon, Y.S., \& Fah, B.C.Y. (2011). "Internet Banking Adoption in Kuala Lumpur: An Application of UTAUT Model.", International Journal of Business and Management, Vol. 6, No. 4, pp. 161-167.

Fryer, K., Antony,J. \& Ogden, S., (2009). "Performance management in the public sector.", International Journal of Public Sector Management, Vol. 22, No. 6, pp. 478-498.

Fueglistaller, U., Klandt, H. \& Halter, F. (2006). International Survey on Collegiate Entrepreneurship 2006, European Business School/University of St. Gallen (eds.). Oestrich-Winkel/St. Gallen.

Gambetta, D., (1988). Trust: Making and Breaking Cooperative Relations, Blackwell.

Garbarino, E. \& Johnson, M.S. (2014), "The trust, different roles of satisfaction, and commitment in customer relationships.", Journal of Marketing, Vol. 63, No. 2, pp. 70-87.

Hite, J. M. \& Hesterly, W. S. (2001). "The evolution of firm networks: From emergence to early growth of the firm", Strategic Management Journal, Vol. 22, No. 3, pp. 275-286.

Howcroft, B., Hamilton, R. \& Hewer, P. (2002), "Consumer attitude and the usage and adoption of home-based banking in the United Kingdom", International Journal of Bank Marketing, Vol. 20, No. 3, pp. 111-121.

Im, I.I., Kim, Y. \& Hang, H.J. (2008), The effect of perceived risk and technology type on users' acceptance of technologies, Information $\mathcal{E}$ Management, Vol. 45, No. 1, pp. 1-9.

Jacoby, J. \& Kaplan, L. B. (1972). The components of perceived risk. Proceedings of the Third Annual Conference of the Association for Consumer Research, pp. 382-393 
Jagongo, A. \& Kinyua, C. (2013). “The Social Media and Entrepreneurship Growth: A New Business Communication Paradigm among SMEs in Nairobi." International Journal of Humanities and Social Science, Vol. 3, No. 10, pp. 213.

Kelman, H. C. (1958). "Compliance, Identification, and Internalization: Three Processes of Attitude Change", Journal of Conflict Resolution, Vol. 2, No. 1, pp. 51-60.

Kim, D. J., Ferrin, D. L., \& Rao, H. R. (2008). A trust-based consumer decision making model in electronic commerce: The role of trust, perceived risk, and their antecedents. Decision Support Systems, Vol. 44, No. 2, pp. 544-564.

Larpsiri, R. \& Speece, M. (2003). Consumer response to sales forces automation in the insurance industry, Proceedings of the World Marketing Congress, Academy of Marketing Science, Perth, June.

Lee, D., Hosanagar, K., \& Nair, H. S. (2013). The effect of advertising content on consumer engagement: Evidence from Facebook. Available at SSRN. Retrieved from http://www.researchgate.net/publication/257409065.

Malhotra, Y., \& Galletta, F. D. (1999). Extending the Technology Acceptance Model to Account for Social Influence: Theoretical Bases and Empirical Validation, Proceeding of the 32nd Hawaii International Conference on System Sciences.

Mangold, W. G. \& Faulds, D. J. (2009). Social media: The new hybrid element of the promotion mix. Business horizons, Vol. 52, No. 4, pp. 357-365.

Marchand, J. \& Sood, S. (2014). "The alchemy of student entrepreneurs: towards a model of entrepreneurial maturity.", International Journal of Entrepreneurship and Innovation Management, Vol. 18, pp.75-92.

McKnight, D. H., et al. (2002). Developing and validating trust measures for ecommerce: An integrative typology. Information systems research, Vol. 13, No. 3, pp. 334-359.

Min, Q., Ji, S., \& Qu, G. (2008). Mobile commerce user acceptance study in China: a revised UTAUT model. Tsinghua Science \& Technology, Vol. 13, No. 3, pp. 257-264.

Mintzberg, H. (1983). Structure in Fives: Designing Effective Organizations, Prentice-Hall, New Jersey.

Moe, W.W. \& Fader, P.S. (2004), Dynamic conversion behavior at e-commerce sites, Management Science, Vol. 50, No. 3, pp. 326-335.

Moore, G. C., \& Benbasat, I. (1991). Development of an instrument to measure the perceptions of adopting an information technology innovation. Information systems research, Vol. 2, No. 3, pp.192-222.

Noorshella Binti Che Nawi, et al, (2017). "Acceptance and usage of social media as a platform among student entrepreneurs.", Journal of Small Business and Enterprise Development, Vol. 24, No. 2, pp.375-393,

Nysveen, H., Pedersen, P. E., \& Thorbjørnsen, H. (2005). “Explaining intention to use mobile chat services: Moderating effects of gender." Journal of Consumer Marketing. Vol. 22. No. 5. pp. 247- 256.

O'Reilly, C. A., III, \& Chatman, J. (1986). “Organizational commitment and psychological attachment: The effects of compliance, identification, and internalization of prosocial behavior.", Journal of Applied Psychology, Vol. 71, pp. 492-499.

Pink, D. (2009). Drive: The surprising truth about what motivates us. New York: Riverhead Books.

Porter, M.E., (2003). "Strategy and the Internet, Harvard Business Review, March, pp. 1-20.

Prasetyo, H. B., \& Anubhakti, D. (2011), "Kajian Penerimaan Sistem E-Learning Dengan Menggunakan Pendekatan UTAUT: Studi kasus Fakultas Teknologi Informasi Universitas Budi Luhur", Jurnal BIT, Vol. 8, No. 2, pp. 45-47.

Purewal, S. (2001). This Entrepreneur Makes You Laugh, The Tribune India, http://www.tribuneindia.com/2001/20010627/biz.htm> 
Qualman, E., (2009). "Socialnomics: how social media transforms the way we live and do business.", Journal of Comparative Aesearch in Anthropology and Sociology, Vol. 1, No. 2, pp. $225-228$

Rahman, H., Oktavia, S., \& Besra, E., (2019). "Psycho-Cultural Perspective on the Formation of Entrepreneurial Culture of Minangkabau Tribe in West Sumatra Indonesia", Udayana Journal of Law ad Culture, Vol. 3, No. 1, pp. 53-77

Rahman, H., \& Day, J. (2015). "Involving the Entrepreneurial Role Model: A Possible Development for Entrepreneurship Education." Journal of Entrepreneurship Education, Vol. 18, No. 1, pp. 86-95.

Salim, B. (2012). "An application of UTAUT model for acceptance of social media in Egypt: A statistical study." International Journal of Information Science, Vol. 2, No. 6, pp.92-105.

Schiffman, L.G., \& Kanuk, L. (2000). Consumer Behaviour. Upper Saddle River, NJ: Prentice Hall.

Shambare, R. (2013). "Barriers to Student Entrepreneurship in South Africa", Journal of Economics and Behavioural Studies, Vol. 5, No. 7, pp. 449-459.

Shokery, N.M.B.A.H., et al. (2016), "Factors contributing to the acceptance of social media as a platform among student entrepreneurs: a review", Mediterranean Journal of Social Sciences, Vol. 7, No. 2, pp. 42-51

Soopramanien, D.G.R. \& Robertson, A. (2007), "Adoption and usage of online shopping: an empirical analysis of the characteristics of 'buyers' 'browsers' and 'non-internet shoppers", Journal of Retailing and Consumer Services, Vol. 14, No. 1, pp. 73-82.

Šumak, B. \& Šorgo, A. (2016), The acceptance and use of interactive whiteboards among teachers: differences in UTAUT determinants between pre-and post-adopters, Computers in Human Behavior, Vol. 64, pp. 602-620,

Tan, K.S., Chong, S.C. \& Lin, B. (2013). Intention to use internet marketing: a comparative study between Malaysians and South Koreans, Kybernetes, Vol. 42, No. 6, pp. 888-905.

Thompson, R., Christoper, A., \& Howell, J. (1991). Personal Computing: Toward a Conceptual Model of Utilization. MIS Quarterly.

Tung, F.C., Chang, S.C. \& Chou, C.M. (2008), "An extension of trust and TAM model with IDT in the adoption of the electronic logistics information system in HIS in the medical industry", International Journal of Medical Informatics, Vol. 77, No. 5, pp. 324-335

Venkatesh, V., et al. (2003). User acceptance of information technology: Toward a unified view. MIS Quarterly, Vol. 27, No. 3, pp. 425-478.

Venkatesh, V., \& Zhang, X. (2010). "Unified theory of acceptance and use of technology: U.S. vs. China.", Journal of Global Information Technology Management, Vol. 13, No. 1, pp. 5-27 